\title{
Effects of calcium channel on ovarian cancer cells
}

\author{
CHUNYUN ZHANG* ${ }^{*}$ and HAILING LI* \\ Department of Obstetrics and Gynecology, Dongying People's Hospital, Dongying, Shandong 257091, P.R. China
}

Received March 7, 2016; Accepted January 3, 2017

DOI: $10.3892 / \mathrm{ol} .2017 .7061$

\begin{abstract}
The aim of the present study was to examine the effects of calcium channel protein on ovarian cancer cells. The expression of calcium channel protein in normal ovarian cells and ovarian cancer cells was detected by fluorescence quantitative PCR. Subsequently, the ovarian cancer cells were added to calcium channel protein activator media at various concentrations of $0,1,4,8,12,16$ and $20 \mathrm{mmol} / 1$. The concentration of calcium ion in different samples was produced, and using an MTT assay, ovarian cancer cell activity in various samples was detected. Finally, a flow cytometer was used to explore the apoptosis rate. It was found that there was a significant difference between the expression of calcium channel protein in normal ovarian tissue and ovarian cancer cells $(\mathrm{P}<0.05)$, as well as a significant difference of calcium concentration among various samples $(\mathrm{P}<0.05)$. When the concentrations of calcium channel activator were 1, 4, 8, 12, 16 and $20 \mathrm{mmol} / \mathrm{l}$, the values of the ovarian cancer cell inhibition rates were 4.6, $21.3,48.3,67.9,52.8$ and $31.8 \%$, respectively. It showed that the calcium channel activator inhibited the proliferation of ovarian cancer cells to a certain extent, in a dose-dependent manner, especially when the concentration was at $12 \mathrm{mmol} / \mathrm{l}$ at which the intracellular calcium concentration was similar to that in normal ovarian cells. In conclusion, calcium ions play an important role in promoting cell proliferation of ovarian cancer cells, and they were involved in apoptosis of ovarian cancer cells to some extent, which regulates apoptosis by controlling the content of intracellular calcium.
\end{abstract}

\section{Introduction}

Ovarian cancer has become a common malignant tumor in the reproductive system of women, and the mortality rate is higher than other diseases (1). Statistics revealed that there are $\sim 210,172$ cases of ovarian cancer and $\sim 104,683$ deaths of

Correspondence to: Dr Hailing Li, Department of Obstetrics and Gynecology, Dongying People's Hospital, 317 Nanyi Road, Dongying, Shandong 257091, P.R. China

E-mail: rmyyzyp2009@163.com

${ }^{*}$ Contributed equally

Key words: calcium channel protein, ovarian cancer cells, activator, apoptosis, flow cytometry women due to this disease in 2008 (2). A study by Tamura (3) showed that most of women in the first diagnosis of ovarian cancer already have different degrees of metastasis in that the early symptoms of ovarian cancer were not obvious. It is believed that the key reason for this was that most patients could not obtain an early diagnosis (4). At present, it is confirmed that early diagnosis of stage I can be cured in $90 \%$ and stage II in $70 \%$ of the patients (5). Therefore, promoting studies on the pathogenesis of ovarian cancer may help us to identify the disease in the early or curable stage, and to provide a new and effective treatment.

Calcium channel protein is essential for maintaining calcium homeostasis inside and outside the cell (6). Previous evidence showed that calcium ions in the cells acted as intracellular messengers, and played a regulatory role in many metabolism and physiological activities of cells, such as mediation of cell metabolism rate, controlling the contraction of muscle cells, regulating cell secretion and division, as previously suggested (7-10). It was found that calcium ions may be involved in some crucial death processes of cells, and too many calcium ions may cause different degrees of cell death, which may be the main mechanism of cardiomyopathy caused by ischemia (11). Researchers also suggested that the destruction of intracellular calcium homeostasis may be closely associated with the occurrence of certain cancers (12-14). Although the increase of intracellular calcium concentration can result in cell apoptosis and even death, there is scarce research on the calcium channel protein in ovarian cancer cells (15).

Therefore, in this study, we investigated the role of calcium channel protein in ovarian cancer cells, in order to provide some theoretical and experimental basis for follow-up study and clinical ovarian cancer treatment.

\section{Materials and methods}

Experimental reagents. Calcium channel protein activator (nicardipine) was purchased from Sigma Chemical Co. (St. Louis, MO, USA), and methyl thiazolyl tetrazolium (MTT) assay from Shanghai Biological Engineering Co., Ltd. (Shanghai, China), while fluorescence quantitative polymerase chain reaction (PCR) reagents were from Takara (Tokyo, Japan).

Ovarian cancer cell line and its culture. Human ovarian cells were purchased from CICC and preserved in liquid nitrogen. The culture condition was $37^{\circ} \mathrm{C}, 5 \% \mathrm{CO}_{2}$, and $10 \%$ fetal bovine serum (Roche, Basel, Switzerland) was added in the 
culture medium, and $0.25 \%$ trypsin was used for digestion in each passage.

Extraction and fluorescence quantitative PCR of ovarian cancer cell RNA. Frozen tissue samples $(0,1 \mathrm{~g})$ were taken from liquid nitrogen and thawed on ice. Subsequently, $0.45 \mathrm{ml}$ of RNA Plus was added, followed by homogenization with mortar in an Eppendorf tube. The contents were later transferred into the centrifuge tube after washing. Next, $200 \mu \mathrm{l}$ of chloroform was added and mixed with vortexing for $15 \mathrm{sec}$. The tube contents were centrifuged at $10,500 \mathrm{x} \mathrm{g}, 4^{\circ} \mathrm{C}$ for $15 \mathrm{~min}$. After that the supernatant was transferred to an EP tube (RNase removed) with an equal volume of isopropanol, and it was reversed, and mixed while keeping on ice for $10 \mathrm{~min}$. The tube was centrifuged again as previously and the supernatant was removed, then $750 \mu 1$ of $75 \%$ ethanol was added and mixed gently, followed by centrifugation at $10,500 \times \mathrm{g}, 4^{\circ} \mathrm{C}$, for $10 \mathrm{~min}$. The supernatant and ethanol that remained were removed. Finally, appropriate amount of RNase-free water was added to the RNA pellet. The extracted RNA was assessed for quality and quantity, before proceeding for reverse transcription. The operation referred to the fluorescence quantitative PCR instructions of Takara with a slight change.

Determination of intracellular calcium concentration. The calcium concentration in ovarian cancer cells and normal ovarian cells was determined as described elsewhere (16), to detect the intracellular free calcium concentration in human erythrocytes.

MTT assay used for cell activity. One hundred microliters of ovarian cancer cells with a concentration of $2 \times 10^{4} / \mathrm{ml}$ were cultured in 96-well plates. After $12 \mathrm{~h}$, calcium protein activator of different concentrations $(0,1,4,8,12,16$ and $20 \mathrm{mmol} / 1)$ was added into each well with 3 replicates in each group. After culturing under conditions of $37^{\circ} \mathrm{C}, 5 \%$ and $\mathrm{CO}_{2}$ for $48 \mathrm{~h}$, $20 \mu \mathrm{l}$ of MTT reagent was added into each well. After $4 \mathrm{~h}$, the medium was removed and $100 \mu \mathrm{l}$ of DMSO detection reagent was added, followed by agitation. Light absorption values (A) were detected at $490 \mathrm{~nm}$. The cell inhibition rate was calculated as: (the value of $\mathrm{A}$ in the control group - $\mathrm{A}$ in the calcium channel activator group)/the value of $\mathrm{A}$ in the control group x $100 \%$.

Flow cytometry used to detect apoptosis. Trypsin was used to digest ovarian cancer cells grown in different activators for $48 \mathrm{~h}$, followed by gentle washing 3-5 times with sterile phosphate-buffered saline (PBS) (pH 7.2) and then fixed with $80 \%$ cold ethanol. After the treatment, ovarian cancer cells were placed at $-20^{\circ} \mathrm{C}$ overnight, and were rinsed with PBS 3-5 times the next day to remove remaining ethanol. After cell counting, the cell concentration was set to $1 \times 10^{6} / \mathrm{ml}$. PI dye $(50 \mu \mathrm{l} / \mathrm{ml})$ was added at room temperature and out of direct sunlight for $30 \mathrm{~min}$. Flow cytometry was then used to detect each sample for $2 \times 10^{5}$ cells. Analysis was carried out by CellQuest software.

Hoechst 33258 staining. For detection of cell morphology, Hoechst 33258 staining was performed according to the manufacturer's instructions.

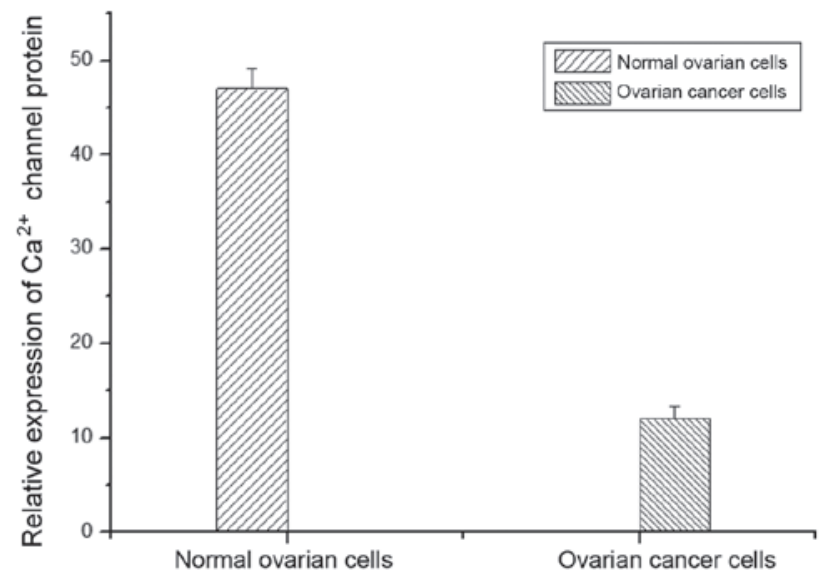

Figure 1. Expression of $\mathrm{Ca}^{2+}$ channel protein in normal ovarian cells and ovarian cancer cells.

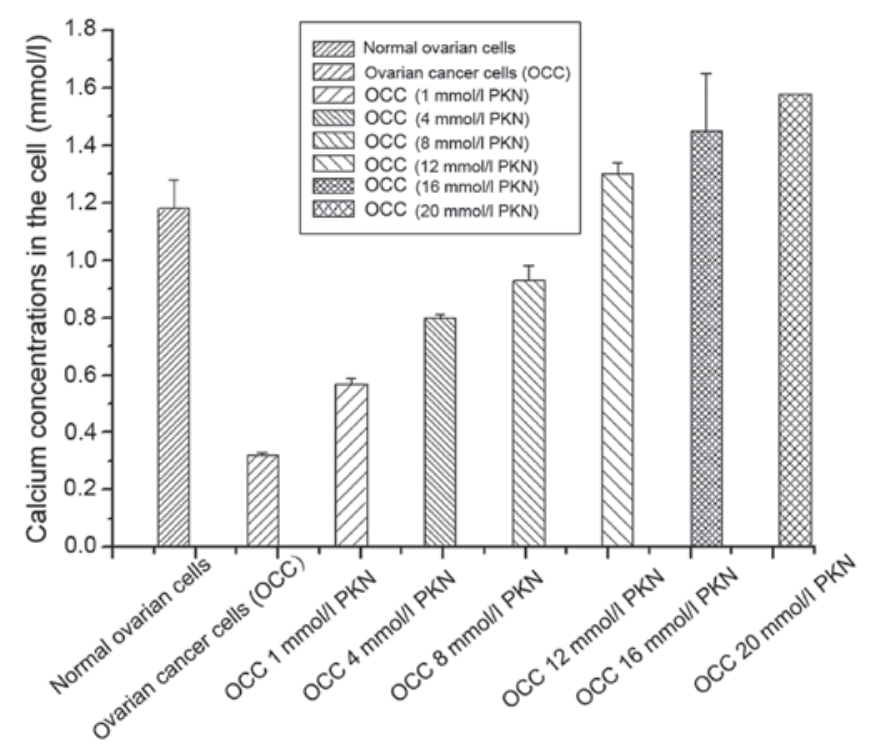

Figure 2. Calcium contents in ovarian cancer cells (OCC) treated with different calcium channel protein activators.

Statistical analysis. SPSS 20.0 software (Chicago, IL, USA) was used for analysis of data. Related measurement results are expressed as mean \pm standard deviation and measurement data were detected by $\chi^{2}$ test.

\section{Results}

Expression of calcium channel protein in different cells. In this study, fluorescent quantitative PCR was applied to detect the expression of calcium channel protein in normal ovarian cells and ovarian cancer cells. As shown in Fig. 1, the expression of calcium channel protein in normal cells was significantly higher than that of ovarian cancer cells.

Calcium content in ovarian cancer cells after treatment with different calcium channel protein activators. Calcium concentrations in ovarian cancer cells were detected after treatment with different calcium channel protein activators. It was found that calcium concentration in normal ovarian cells 
Table I. Effects of different concentrations of calcium channel protein activator on ovarian cancer cell proliferation.

\begin{tabular}{lcc}
\hline Group & A450 & $\begin{array}{c}\text { Cell proliferation } \\
\text { inhibitory rate (\%) }\end{array}$ \\
\hline $\begin{array}{l}\text { Control (normal } \\
\text { ovarian cells) }\end{array}$ & $0.796 \pm 0.0328$ & \\
Treatment (calcium & & \\
channel protein & & \\
activator) (mmol/l) & & \\
1 & $0.736 \pm 0.0348$ & $4.6^{\mathrm{a}}$ \\
4 & $0.648 \pm 0.0213$ & $21.3^{\mathrm{a}}$ \\
8 & $0.547 \pm 0.041$ & $48.3^{\mathrm{a}}$ \\
12 & $0.376 \pm 0.0027$ & $67.9^{\mathrm{b}}$ \\
16 & $0.485 \pm 0.016$ & $52.8^{\mathrm{a}}$ \\
20 & $0.591 \pm 0.02$ & $31.8^{\mathrm{a}}$ \\
\hline
\end{tabular}

${ }^{\mathrm{a}} \mathrm{P}<0.05,{ }^{\mathrm{b}} \mathrm{P}<0.01$, significant difference.
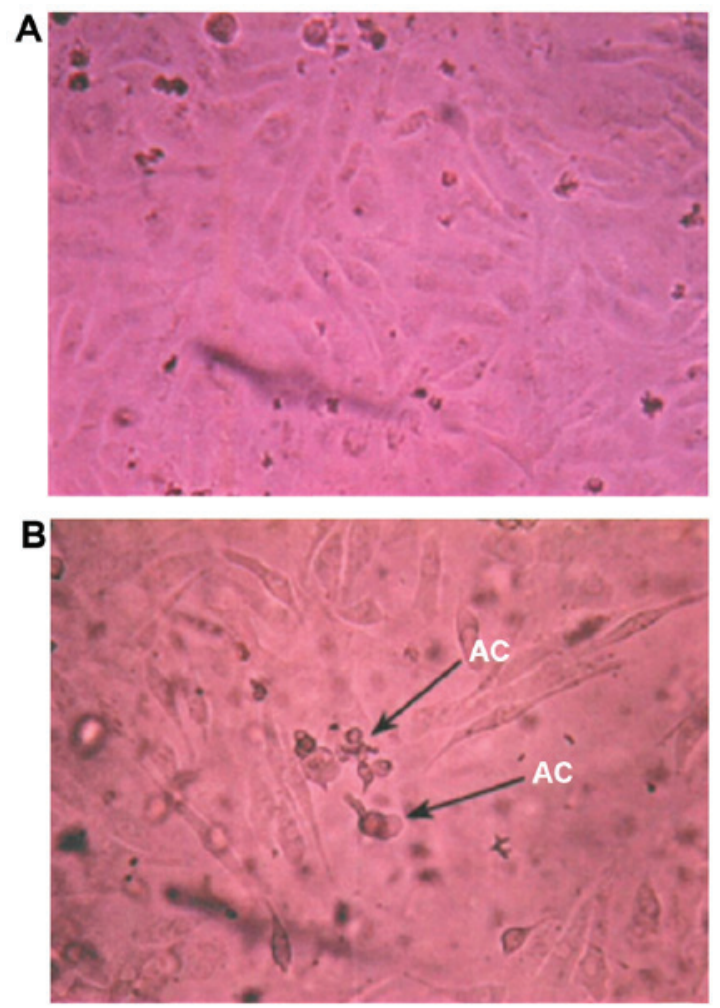

Figure 3. Effects of calcium channel protein activator on ovarian cancer cell proliferation (magnification, x200). (A) Control group and (B) $12 \mathrm{mmol} / \mathrm{l}$ calcium channel protein activator. AC, apoptotic cells.

(the control group) was significantly higher than untreated ovarian cancer cells with calcium channel protein activator. With increase of the concentration of the activator, the intracellular calcium concentration showed a downward trend after the first increase (Fig. 2).

Inhibitory effects of different calcium channel protein activators on ovarian cancer cells. MTT assay showed that when the
Table II. Effects of calcium channel protein activator on apoptosis of ovarian cancer cells (mean $\pm \mathrm{SD}, \mathrm{n}=12$ ).

\begin{tabular}{lc}
\hline Group & Cell apoptosis rate $(\%)$ \\
\hline Control & $2.13 \pm 0.017$ \\
Treatment (calcium channel & \\
protein activator) $(\mathrm{mmol} / \mathrm{l})$ & \\
1 & $54.8 \pm 0.042^{\mathrm{a}}$ \\
4 & $65.7 \pm 0.012^{\mathrm{a}}$ \\
8 & $74.2 \pm 0.068^{\mathrm{a}}$ \\
12 & $83.4 \pm 0.037^{\mathrm{b}}$ \\
16 & $79.6 \pm 0.024^{\mathrm{a}}$ \\
20 & $67.3 \pm 0.042^{\mathrm{a}}$ \\
\hline
\end{tabular}

${ }^{\mathrm{a}} \mathrm{P}<0.05,{ }^{\mathrm{b}} \mathrm{P}<0.01$, significant difference compared with control group.
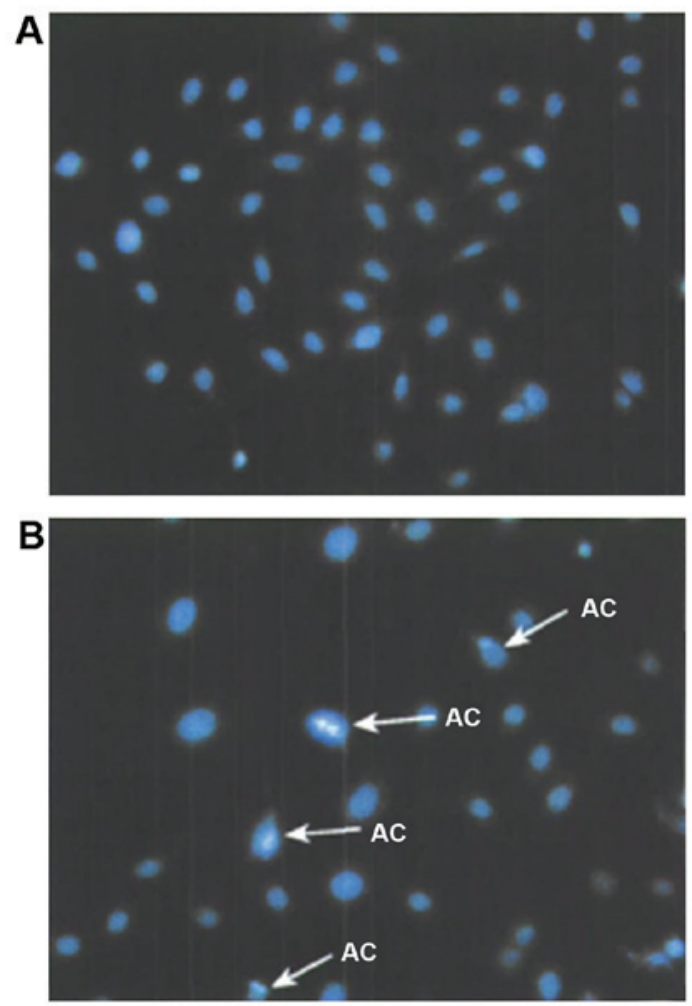

Figure 4. Effects of calcium channel protein activator on ovarian cancer cell apoptosis. (A) Control group and (B) $12 \mathrm{mmol} / 1$ calcium channel protein activator. AC, apoptotic cells.

concentrations of calcium channel protein activator were 1,4 , $8,12,16$ and $20 \mathrm{mmol} / \mathrm{l}$, the proliferation inhibition rates of ovarian cancer cells were 4.6, 21.3, 48.3, 67.9, 52.8 and 31.8\%, respectively. It was indicated that the inhibitory effects of calcium channel protein activator on the proliferation of ovarian cancer cells applied in a dose-dependent manner, which was more obvious when the activator concentration was at $12 \mathrm{mmol} / \mathrm{l}$ (Table I). When the concentration of calcium channel protein activator was $12 \mathrm{mmol} / \mathrm{l}$ at $48 \mathrm{~h}$, ovarian cancer cells became round, the cell membrane showed blebbing, refractive index decreased and apoptotic bodies emerged (Fig. 3). 
Observation of apoptosis of ovarian cancer cells induced by calcium channel protein activator. Ovarian cancer cells were treated with calcium channel protein activator with a concentration of $12 \mathrm{mmol} / \mathrm{l}$ for $48 \mathrm{~h}$, and followed by PBS washing and Hoechst 33258 staining. The cells were then observed through a fluorescent microscope, as shown in Fig. 4. In the treatment group, apoptosis of nucleus chromatin showed a condensed state, which turned highly condensed and marginalized in late apoptosis along with cell division.

Flow cytometry for apoptosis of ovarian cancer cells induced by calcium channel protein activator. It was found that for apoptosis in ovarian cancer cells induced by calcium channel protein activator (Table II), the apoptosis rates ( $48 \mathrm{~h}$ later) were $5.4,23.8,51.2,68.4,53.8$ and $36.7 \%$ with calcium channel protein activators at $1,4,8,12,16$ and $20 \mathrm{mmol} / 1$, respectively. There was a significant difference compared with the control group $(1.73 \%)(\mathrm{P}<0.05)$. It indicates that calcium channel protein can promote apoptosis of ovarian cancer cells by increasing the intracellular calcium concentration, which was consistent with the MTT results.

\section{Discussion}

In this study, we proved that compared with normal ovarian cells, calcium concentration was significantly lower in the ovarian cancer cells and calcium channel protein activator can induce apoptosis in ovarian cancer cells by increasing the intracellular calcium concentration. It showed that calcium ions can participate in regulating apoptosis of ovarian cells to a certain extent. Previous findings showed that the lack of intracellular calcium can lead to redox imbalance in the cells, followed by the damage of intracellular membrane (17-19). Braga et al proved that in ovarian cells, calcium ions can interact with other intracellular factors such as AMP to regulate the early cell apoptosis (20). Other studies have shown that the intracellular calcium-regulating enzyme can regulate the cell apoptosis by acting downstream of cytosolic calcium; however, the mechanism of action remains unclear (21).

Li et al suggested that the calcium ions in the cell may be associated with some tumor suppressor genes to regulate the apoptosis of malignant cells; however, the mechanism of action is still unknown (22). After studying the relevant research, we found that there are theories demonstrating that calcium ions are involved in the regulation of apoptosis in late apoptosis as intracellular signals. However, there is no related experiment on the interactions between calcium ions and ovarian cancer cells. Therefore, in this study, to the best of our knowledge, we identified for the first time that calcium ion can regulate cell apoptosis through its intracellular content in a dose dependent manner.

\section{References}

1. Guppy AE, Nathan PD and Rustin GJ: Epithelial ovarian cancer: a review of current management. Clin Oncol (R Coll Radiol) 17: 399-411, 2005.

2. Yan XD: Comparative proteomics analysis on resistant proteins of ovarian cancer platinum drugs and the analysis of functions of drug resistant proteins Annexin A3 (unpublished $\mathrm{PhD}$ dissertation). Peking Union Medical University, 2008. http://cdmd. cnki.com.cn/article/cdmd-10023-2009063673.htm.
3. Tamura G: Hypermethylation of tumor suppressor and tumor-related genes in neoplastic and non-neoplastic gastric epithelia. World J Gastrointest Oncol 1: 41-46, 2009.

4. Boente MP, Godwin AK and Hogan WM: Screening, imaging, and early diagnosis of ovarian cancer. Clin Obstet Gynecol 37: 377-391, 1994.

5. Verhagen AM and Vaux DL: Cell death regulation by the mammalian IAP antagonist Diablo/Smac. Apoptosis 7: 163-166, 2002.

6. Antonsson B: Bax and other pro-apoptotic Bcl-2 family 'killer-proteins' and their victim the mitochondrion. Cell Tissue Res 306: 347-361, 2001.

7. Zhang M, Li Y, Zhang H and Xue S: BAPTA blocks DNA fragmentation and chromatin condensation downstream of caspase-3 and DFF activation in HT-induced apoptosis in HL-60 cells. Apoptosis 6: 291-297, 2001.

8. Veldhuis JD and Klase PA: Mechanisms by which calcium ions regulate the steroidogenic actions of luteinizing hormone in isolated ovarian cells in vitro. Endocrinology 111: 1-6, 1982.

9. Veldhuis JD and Klase PA: Calcium ions modulate hormonally stimulated progesterone production in isolated ovarian cells. Biochem J 202: 381-386, 1982

10. Gao SY, Wang QJ and Ji YB: Effect of solanine on the membrane potential of mitochondria in HepG2 cells and $\left[\mathrm{Ca}^{2+}\right] \mathrm{i}$ in the cells. World J Gastroenterol 12: 3359-3367, 2006.

11. Monteiro P, Oliveira PJ, Gonçalves L and Providência LA: Mitochondria: role in ischemia, reperfusion and cell death. Rev Port Cardiol 22: 233-254, 2003.

12. Wang JY, Chen BK, Wang YS, Tsai YT, Chen WC, Chang WC, Hou MF, Wu YC and Chang WC: Involvement of store-operated calcium signaling in EGF-mediated COX-2 gene activation in cancer cells. Cell Signal 24: 162-169, 2012.

13. Hajnóczky G, Davies E and Madesh M: Calcium signaling and apoptosis. Biochem Biophys Res Commun 304: 445-454, 2003.

14. Liu ZM, Chen GG, Vlantis AC, Tse GM, Shum CK and van Hasselt CA: Calcium-mediated activation of PI3K and p53 leads to apoptosis in thyroid carcinoma cells. Cell Mol Life Sci 64: 1428-1436, 2007.

15. Naziroğlu $M$ and Lückhoff A: A calcium influx pathway regulated separately by oxidative stress and ADP-Ribose in TRPM2 channels: single channel events. Neurochem Res 33: 1256-1262, 2008.

16. Yorek MA, Davidson EP, Dunlap JA and Stefani MR: Effect of bradykinin on cytosolic calcium in neuroblastoma cells using the fluorescent indicator fluo-3. Biochim Biophys Acta 1177: 215-220, 1993.

17. Zhang X, Ng WL, Wang P, Tian L, Werner E, Wang H, Doetsch $P$ and Wang Y: MicroRNA-21 modulates the levels of reactive oxygen species by targeting SOD3 and TNFa. Cancer Res 72: 4707-4713, 2012.

18. Walter L and Hajnóczky G: Mitochondria and endoplasmic reticulum: The lethal interorganelle cross-talk. J Bioenerg Biomembr 37: 191-206, 2005.

19. Dulce RA, Yiginer O, Gonzalez DR, Goss G, Feng N, Zheng M and Hare JM: Hydralazine and organic nitrates restore impaired excitation-contraction coupling by reducing calcium leak associated with nitroso-redox imbalance. J Biol Chem 288: $6522-6533,2013$.

20. Braga EA, Loginov VI, Klimov EA, Kilosanidze G, Khodyrev DS, Kaganova NL, Kazybskaia TP, Ermilova VD, Gar'kavtseva RF, Pronina IV, et al: Activation of RHOA gene transcription in epithelial tumors may be caused by gene amplification and/or demethylation of its promotor region. Mol Biol (Mosk) 40: 865-877, 2006 (In Russian).

21. Pani G, Galeotti T and Chiarugi P: Metastasis: cancer cell's escape from oxidative stress. Cancer Metastasis Rev 29: 351-378, 2010.

22. Li X, Lin G and Zhou K: Research Progress on the relationship between tumor suppressor gene PTEN and cell apoptosis. J Guangdong Medical College 23: 676-678, 686, 2005 (In Chinese). 